\title{
THE IMPLEMENTATION ANALYSIS OF ISMA' WA TAKALLAM METHOD IN LEARNING SPEAKING SKILL FOR NON-ARABIC SPEAKERS AT MA'HAD MU'ALLIMIL QURAN, EGYPT
}

\author{
Tsara Aliya Salsabila ${ }^{1}$, Maman Abdurrahman², Mohamad Zaka Al Farisi ${ }^{3}$ \\ 1,2,3Fakultas Pendidikan Bahasa dan Sastra UPI \\ 1,2,3Jl. Dr. Setiabudi No. 229, Bandung \\ Email: tsara.aliya@gmail.com ${ }^{1}$, mamanabdurrahman@upi.edu² ${ }^{2}$ zaka@upi.edu ${ }^{3}$
}

\begin{abstract}
:
This research aimed to analyze the implementation and evaluation system of Arabic teaching using Isma 'wa Takallam method in improving Arabic speaking skill. The method used in this research was descriptive method with qualitative approach through observational research. The subjects were 2 students who participated in Sandwich program in Egypt. The study was conducted in Ma'had Mu'allimil Quran, Giza, Egypt. The instruments used were observation, interview, and documentation. The data obtained were analyzed using Miles and Huberman model. The results indicated that the process of teaching Arabic using this method through three stages, namely: (1) Nurul Bayan learning (learning the pronunciation of hijaiyyah, spelling Qur'an verses, and tajweed), (2) learning Arabic (basic rules, muhadatsah, reading Arabic texts, and Arabic poetry), and (3) practice speaking Arabic, both inside and outside the classroom. The evaluation system used was oral test conducted during the learning process and at the end of the program.
\end{abstract}

\begin{abstract}
Abstrak:
Penelitian ini bertujuan untuk mengetahui proses pelaksanaan dan sistem evaluasi pembelajaran bahasa Arab dengan metode Isma' wa Takallam dalam meningkatkan keterampilan berbicara bahasa Arab. Metode yang digunakan dalam penelitian ini adalah metode deskriptif dengan pendekatan kualitatif melalui studi observasi. Subjek penelitian ini adalah 2 mahasiswa yang berpartisipasi pada program Sandwich di Mesir. Penelitian dilakukan di Ma'had Mu'allimil Quran, Giza, Egypt. Instrumen yang digunakan adalah observasi, wawancara, dan dokumentasi. Data yang didapatkan dianalisis menggunakan model Miles dan Huberman. Hasil penelitian menunjukkan bahwa proses pelaksanaan pembelajaran bahasa Arab dengan metode ini melalui tiga tahap, yaitu: (1) pembelajaran Nurul Bayan (pembelajaran pengucapan huruf-huruf hijaiyyah, mengeja Al-Qur'an, dan ilmu tajwid), (2) pembelajaran bahasa Arab (kaidah dasar, muhadatsah, membaca teks Arab, dan syair Arab), dan (3) praktik berbicara bahasa Arab, baik di dalam kelas maupun di luar kelas. Sistem evaluasi menggunakan tes lisan yang dilaksanakan pada saat proses pembelajaran berlangsung dan pada akhir pembelajaran.
\end{abstract}

\section{Keywords:}

Isma' wa Takallam, Speaking Skill, Learning Method

How to Cite: Salsabila, T. A., Abdurrahman, M., \& Al Farisi, M. Z. (2020). The Implementation Analysis of Isma' Wa Takallam Method in Learning Speaking Skill for Non-Arabic Speakers at Ma'had Mu'allimil Quran, Egypt. Lentera Pendidikan : Jurnal Ilmu Tarbiyah dan Keguruan, 23(1), 6985. https://doi.org/10.24252/lp.2020v23n1i7. 


\section{INTRODUCTION}

A person who studies a language must have language skills. According to Nashri (2014: 252), there are four language skills; they are listening, speaking, reading and writing. The four aspects are interrelated and interacted. In addition, Achmad (2017: 2) points out that someone's speaking skill is determined by the capability of his or her listening and reading skill contributes to writing competence and vice-versa. A study conducted by Srimelisa, Thahar, \& Arief (2019) reveals that reading and writing have a very close relationship; the better someone's reading comprehension, the better his/her writing skill. Mufidah \& Zainudin (2018) also state that two basic skills taught at the beginning of language learning are listening and speaking skills. According to Ruswandi, (2011: 66), speaking is one of the productive skills in language study. Learners' speaking skill is directly understood or measured whether they are productive or not. Accordingly, they are called skillful if they always produce utterances through their vital organ of speech namely mouth. Mustofa (2018: 2) further adds that listening skill is the basic of good speaking skill; if someone's listening skill is low, it can be predicted that he cannot retell the topic as he has heard properly.

Chaer (2009: 243) states that a language can be learnt in two ways: (1) through naturalistic learning type, that is learning in the natural environment, and (2) through formal natural type, that is learning in the classroom. Concerning to the language acquisition, in the perspective of Psycholinguistics, the role of native speaker is very important in introducing the culture of his language, the way of thinking, believe, tradition, history and the way of life. In addition, Anshari (2018: 62) states that the taste of language or the process of understanding certain language as spoken and understood by the native speakers can be done either through direct interaction with native speaker continuously and intensively or from reading result of literary works produced by native speaker. The presence of native speaker can be useful to enhance Arabic language skills either formally (in the classroom) or informally (outside the classroom). Salam (2014) explains the statement of Hatch and Ellis that the native speaker acts as communication developer, relationship builder with the students, and learning model. Hence, the presence of native speaker as a teacher in the classroom and in the natural context will help the foreign language students understand the thought and feeling of the target language and culture of the community. Native speaker who speaks and expresses his/her idea in native language will defineltely help the students learn the foreign language, especially in pronunciation.

Viriya \& Sapsirin (2014: 80) point out the statement of Oxford (1990) that proposes two main classes of language learning strategies; they are direct and indirect. Direct class consists of: (1) memory strategy which directly involves target language which consists of creating mental connection, applying image and sound, reviewing properly, and using action; (2) cognitive strategy, such as summarizing or reasoning deductively, allowing students to figure out and develop new language in many ways; and (3) compensation strategy, such as guessing or using synonym which allow students to use the language even though they have discrepancy of knowledge. These ways help the students understand and 
use target language by practicing it. Besides, indirect class (does not involve target language) consists of: (1) metacognitive strategy, that is actions that go beyond pure cognitive devices and provide ways for students to coordinate their own learning process; (2) affective strategy, which refers to emotion, attitude, motivations, and values; and (3) social strategy, that considers language as a form of social behavior as well as communication, and communication takes place among people. Thus, language learning engages other people and appropriate social strategy plays important role in this process.

The objective of language learning is as communication tool. Therefore, it is required an appropriate learning method to achieve the objective. As Habib (2013) points out that modern Arabic learning method is the one that is oriented on the objective of language as a tool. It implies that Arabic is considered as communication tool in modern life. Consequently, the core of Arabic learning is the ability to use the language actively and being competent to comprehend utterances/expression in Arabic. Hidayat \& Ashiddiqi (2018: 125) further state that Arabic language always develops (dynamic-progressive) to be various fields of study, various kinds of concentration, and the problem intricacy in details.

Lavi (2015: 17) states that learning method is basic part of learning and it depends on the teacher's success in his/her work in the classroom. By using the method, a teacher can overcome students' weaknesses as well as explain the information that is contained in the curriculum. Subaihi in Sa'id (2009: 58) explains that good learning is the thing that make someone directly recognizes it by himself/herself in internal strengthening, and it becomes the first duty of a modern teacher that emphasizes the important role of a learner. This statement is also in line with the findings of Ulya (2016: 8), good learning method is a learning method which fosters students' learning activities in which teacher acts as a facilitator and students actively act to construct their knowledge. Besides, Ruswandi (2011: 66) states that in teaching speaking, a teacher must pay attention to students individually, especially in evaluation so that the quality of students can be measured directly whether they are good or not in expressing their idea and opinion in front of the audience or assessor. Afroni (2019) further adds that the presence of method in foreign language learning plays important role in understanding foreign language as well as Arabic.

A teacher should have ability in determining a learning method which is appropriate with the students. Al-Khuliy' (1986: 16) states that a teacher needs to recognize how to teach properly and must be able to master various teaching methodologies in order to make teaching effective. The use of various methods also needs to be consideration for every teacher in order to increase the students' interest and passion in learning (Sauri, 2017: 152). In Egypt, there is a learning method which may suitable to learn Arabic for non-Arabic (Indonesian) speakers to enhance speaking performance. The method is called Isma' wa Takallam which is proposed by Prof. Dr. Mohammed Dawood who is native speaker from Egypt. He developed the method especially for non-Arabic speakers who are eager to learn the language there. 
Isma' wa Takallam is a learning method which is based on listening and then pronouncing. This method is done by listening a lot of Arabic words and sentences such as Arabic conversation from native speakers then what is heard is immediately practiced by repeating it, either the pronunciation or the dialect, especially in formal Arabic language (Dawood, 2009). In using this method, language learning begins by teaching the students listening skill or hearing language sound in the form of words or sentences, then they pronounce them before learning to read and to write (Lutfiana, 2010).

A study conducted by Nurfika (2016) which is aimed at describing the use of Sam'iyah Syafawiyyah method in Arabic subject, especially focuses on students' activeness and improvement of study result, reveals that the method can increase the students' activeness in speaking Arabic at school. Moreover, a research done by Achmad (2017) concerning to the application of As-Sam'iyyah Asy-Syafawiyah method to enhance Arabic speaking skill for the 4th grade students at MI Darussalam 01 Aryojeding Rejotangan Tulungagung suggests that the method can improve speaking skill in Arabic subject, especially in Ashabul Mihnah lesson. It is indicated by the results of pretest, posttest I and posttest II which continuously improve by applying As-Sam'iyyah Asy-Syafawiyah method.

In addition, Arfina (2016) further reports that learning maharah al-kalam by using Sam'iyyah Syafawiyyah method has been applied since long time ago at Madrasah Tsanawiyah Negeri Wonosari. The obstacle of learning maharah al-kalam using this method is learning environment of Arabic language which is monoton, learning facilities which are inadequate, teachers' attention which is lack to the students, and educational background of the students which is diverse.

Isma' wa Takallam method aims to acquire speaking skill in various level of istima' (listening) and speaking Arabic fluently and easily, to eliminate assimilation in pronunciation between Arabic language and similar sound in native language, to overcome Arabic sounds which are difficult to pronunce such as sounds of 2, , , , and to train the easiness way to pronounce Arabic using melody based on appropriate meaning such as happiness, sadness, question, astonishment, disagreement, etc (Dawood, 2009).

One of the institutions that implement Isma' wa Takallam method is Ma'had Mu'allimil Quran in Egypt. This ma'had was built by Prof. Dr. Mohammed Dawood and became the educational facility for local society as well as non-Arabic speakers to learn Arabic. Most of the students who take part in the Sandwich program at Ma'had Mu'allimil Quran in Egypt, still encounter difficulties in communicating with native speakers. It is similar with what faced by most of the students of Arabic Department at general college since their environment does not get used to speaking Arabic.

Based on the explanation, the researcher tries to analyze the use of Isma' wa Takallam method in improving students' speaking ability at Sandwich program UPI in order to investigate the learning plan, the implementation of Isma' wa Takallam method, and the evaluation plan used in enhancing Arabic speaking skills. 


\section{RESEARCH METHOD}

This research used descriptive method with qualitative approach through observational study. This study is a research design conducted by using observation towards description of phenomenon experienced by subject of research without any treatment or intervention of the researcher. In this study, the researcher described, wrote, analyzed, and interpreted the learning plan and Arabic learning process by using Isma' wa Takallam method and its evaluation system toward the enhancement of speaking skill for non-Arabic speakers.

The subjects in this research were two students of Arabic Department at Universitas Pendidikan Indonesia who participated in Sandwich program in Egypt. Both subjects were delegation of the third and the fourth year students as well as the representatives of the lecturer who teached Isma' wa Takallam method. The research took place at Ma'had Mu'allimil Quran, Giza, Egypt. This ma'had was chosen since it was one of institutions that carries out Arabic language learning using Isma' wa Takallam method for non-Arabic speakers.

The instruments used in this research were observation, interview, and documentation. The data were analyzed through Miles and Huberman model, including several steps, they were: (1) data reduction, (2) data presentation, and (3) verification and drawing conclusion. This research began by collecting the relevant data. Then, the collected data were reduced and presented. Finally, verification and drawing conclusion were done by still referring to the results of reduction and presentation of data that have been done.

\section{RESULT AND DICUSSION}

\section{Learning Plan of Isma' Wa Takallam Method}

Before carrying out learning process, there must be a plan. Learning plan using Isma' wa Takallam method is still in the form of dictation guideline. Learning plan is supposed to be syllabus and lesson plan in order to make learning effective and well-structured. Sudrajat (2008) explains that learning plan includes syllabus and lesson plans which contain course identities, standard competencies, basic competencies, indicators of competency achievement, learning objectives, teaching materials, time allotment, learning methods, learning activities, learning outcomes, assessment, and learning resources. The dictation guideline used is as guidelines on learning using Isma' wa Takallam method. It contains the main issues, objectives, steps, scientific training, and learning resources of Isma' wa Takallam method. The dictation guideline can be recognized as curriculum based on article 1 item 19 of Constitution Number 20 Year 2003 on National Education System that curriculum is a set of plans and arrangements concerning objectives, contents, and learning resources as well as method used as guidelines of learning activities in order to achieve aims of certain education. Thus, the content of this dictation guideline meets the curriculum component by the existence of Isma' wa Takallam method objective, learning stages or learning contents, as well as teaching materials used in this method. This 
condition is in line with Heryanto (2016) states that the components of curriculum include component of objectives, component of content/learning materials, component of methods/strategies, and component of evaluation.

The existence of this dictation guideline leads the learning activities directed. As Harjanto (2010: 22) suggests that the importance of learning plan can help the achievement of an objective economically, on time, and provide opportunity to be more easily controlled and monitored in the implementation.

\section{Learning Process of Isma' Wa Takallam Method}

Based on Regulation of Minister of Education and Culture No. 22 year 2016, learning process consists of preliminary activities, core activities and closing activities.

Table 1. Realization of Learning Process

\begin{tabular}{|c|c|c|}
\hline No. & $\begin{array}{c}\text { Learning Process based on } \\
\text { Regulation of Minister of Education } \\
\text { and Culture }\end{array}$ & Realization \\
\hline
\end{tabular}

1. Preliminary activities:
1.1 Prepare the students psychologically and physically to follow the learning process, for instance, the lecturer must observe the students' condition.
1.2 Motivate the students contextually as the benefit and application of teaching materials in daily life by giving example and comparison of local, national, and international, also adjusted with students' characteristics and levels.

1.3 Ask questions related to prior knowledge and materials which are going to be studied.

1.4 Explain the objective of learning or basic competence which is going to be achieved.

1.5 Convey the scope of materials and describe the detail of activities according to syllabus.

- In the next day, lecturer asked questions concerning materials that had been studied before.

- Lecturer only explained learning objectives in the first day.

- Lecturer explained the steps of learning activities which would be studied while they were at ma'had in the first day.

2. Core activities:
2.1 Deliver learning materials.

- Lecturer explained learning materials in accordance with stages 
2.2 Use teaching method.

2.3 Utilize media/learning tools.

2.4 Ask question, provide reinforcement, as well as teaching and learning interaction.

3. Closing activities:

3.1 Reflect to evaluate the whole set of learning activities and the results obtain in order to gain the benefit of the studied materials.

3.2 Provide feedback towards the process and the result of learning.

3.3 Do follow-up activities in the form of giving assignment, either individually or in group, and inform the learning activity plan for the next meeting. of Isma' wa Takallam learning method. They are nurul bayan materials, Arabic language, and practice speaking Arabic.

- Lecturer explained learning materials using various teaching method such as singing, lecturing, debriefing, discussion, giving assignments, and field trips.

- Lecturer occasionally utilized media/learning tools, such as various funny and unique images associated with materials which are going to be studied, Alquran, printed book, and movie. The learning tools used were whiteboard and markers.

- After explaining the learning materials, lecturer revisited the materials, such as debriefing or practice test at the end of the lesson, like spelling Al-Qur'an and practicing to speak Arabic.

- Lecturer sometimes motivated the students by relating to daily life or the benefit of the studied materials.

- Not realized.

- Lecturer sometimes debriefed about the materials that has been delivered.

- Lecturer gave daily exercises in certain subjects.

- Lecturer closed the meeting by reciting hamdalah and closing pray (kafaratul majlis). 
Table 1 illustrates that in preliminary activities, lecturer had already conducted apperception activities. As Sukirman (2012: 144) points out that apperception activities include: checking students' presence, checking students' understanding of the previous materials, conveying objectives/competences which must be achieved, explaining learning activities which must be done by students during learning process, and informing the benefits that will be gained after they study the materials presented. However, in the realization, lecturer only conveyed the learning objectives in general in the beginning of the lesson and did not inform the benefits that would be gained after studying the materials.

In the core activities, lecturer had done his responsibilities by presenting the materials in accordance with the stages of Isma' wa Takallam learning method. Lecturer explained learning materials using various methods such as singing, lecturing, debriefing, discussion, giving assignment and field study. Ibrahim \& Syaodih (2010:104) mention that kinds of teaching methods include: lecturing, discussion, debriefing, demonstration, experiment, giving assignment, field study, and socio-drama. Singing method was only used in Nurul Bayan subject. Lecturing, debriefing, giving assignment, and doing discussion were used in Nurul Bayan and Arabic subjects. Finally, field study was used outside the classroom by establishing a trip every Friday.

Lecturer occasionally utilized media/learning tools, such as various funny and unique images associated with the presented materials, Al-Qur'an, printed book, and movie. The media are classified into still-visual category, printed media, and audio-motionvisual media. As Ibrahim \& Syaodih (2010: 114) point out Brets' statement regarding media classification as follows: audio-motion-visual media, audio-still-visual media, audiosemi motion media, motion-visual media, still-visual media, audio media, and printed media.

In the closing activities, lecturer and students did not reflect to evaluate the whole set of learning activities and the results obtained in order to gain the benefit of learning process. He/she also did not inform the plan for the next meeting properly; whereas, reflecting to evaluate learning activities is essential in order to find out the ability and comprehension of the students towards the presented materials. Bloom (1956) mentions three domains of learning outcomes, they are cognitive, affective, and psychomotor aspects. As for cognitive aspect, Bloom (1956) elaborates seven levels, they are: knowledge, comprehension, definition, application, analysis, synthesis, and evaluation. Whereas, lecturer debriefed or summarized about the presented materials which implies that he provided feedback towards the process and results as well as fives task every day. Finally, lecturer closed the meeting by reciting closing pray (kafaratul majlis).

The steps of learning Arabic language using Isma' wa Takallam method particularly for two months are as follows:

\section{Learning Sound System by Using Nurul Bayan Method}

Nurul Bayan is a learning process that teaches letters and their vowel marks (harakat), Arabic pronunciation in accordance with the place of articulation of Arabic alphabet (makharijul huruf), and also how to write them. By using this method, the 
students learn how to pronounce Arabic alphabets correctly and fluently. Sa'id (2009:8) mentioned that the rules of Nurul Bayan are three; they are reading letters, reading words, and spelling Al-Qur'an. Reading letters is classified into three; they are spelling letters with three-time repetition, repeating letters without spelling, and reading every three letters.

There several stages in learning Arabic using Nurul Bayan method. Firstly, learning to read Arabic alphabets with different vowel marks or diacritics (fatha, kasra, damma), it is similar with spelling words with three-time repetition, repeating without spelling, and reading every three letters. Secondly, learning to read words with Arabic alphabets, it is very inportant to know the Arabic alphabets. Thirdly, learning to spell Al-Qur'an, like spelling words with three-time repetition, repeating words without spelling, and reading every three letters, the three steps are based on Nurul Bayan rule which mentioned by Sa'id (2009) beforehand. Fourthly, learning resources of Nurul Bayan method, they are the list of Arabic alphabets in one page, book under the title Nurul Bayan li Ta'limil Qir'ah wa Tartilil Qur'an, and tajweed pocketbook. Fifthly, media used in this method is various images of letters containing tajweed and its examples using Arabic words, funny images, and various colorful shapes, letter game and its location. The media is created by the teacher. The use of this kind of media is similar with the one utilized in the research conducted by Mawaddah (2012), that is learning media in the form of images. The image media are created in order to overcome the lack of learning facilities, the low of students' basic abilities, etc. In Nurul Bayan method, these media are created to make learning fun, attract students' attention, help the students understand the materials, etc. Sixthly, other teaching methods used in Nurul Bayan learning are singing, lecturing, discussion, or debriefing. Ibrahim \& Syaodih (2010: 104) states that kinds of teaching method include: lecturing, discussion, debriefing, demonstration, experiment, giving assignment, field study, and socio-drama methods. Lecturer had provided songs for each subject of his, for instance songs for pronouncing Arabic alphabet sounds, Arabic words in accordance with tajweed, and other various tajweed. Seventhly, having presented the whole materials, the lecturer conducted reciting Al-Qur'an test. The verse used was the last verse of Surah AlFath that is verse 29. This verse contains all Arabic alphabets which are 28 letters. The letters are considered consonant in Arabic language. Therefore, this verse becomes the example of Isma' wa Takallam method. The test of reciting Al-Qur'an is conducted every day continuously so the students can be accustomed to speak Arabic correctly. The last, in the final month, the students learned the rhythm in reciting Al-Qur'an from expert lecturer. He is Syekh Abdul 'Al, who taught seven rhythms, they are bayyati, shoba, nahawand, hijaz, rosh, sika, and jiharka then each student practiced the rhythms after the lecturer gave example.

\section{Arabic Language Learning}

Besides learning about Arabic sound system using Nurul Bayan method, the students also learned Arabic language. The learning materials learned were basic rules, balaghah in general, reading Arabic text in a book entitled Maladzul Amin as well as its meaning, and enriching Arabic vocabulary through speaking practice or a text, and writing practice on given students' worksheet. Students also learned poems and its meaning. Then, every 
student explained orally about the poems studied. It is in accordance with stages of Isma' wa Takallam method, that is listening and speaking. As Dawood (2009) contended that there are two stages of Isma' wa Takallam learning method, they are listening to Al-Qur'an and speaking with native speaker using formal language then speaking by direct practice, such as conversation and imitating speech style of native speaker.

\section{Arabic Language Speaking Practice}

Students were divided into groups based on their major. They were the students of Arabic Education Department and Islamic Education Department. The group was used in the first month for speaking practice and conversation with a lecturer in each group. The practice of conversation was based on a theme determined by a lecture or free theme. During one month, the students must have practiced conversation with new words according to predetermined theme, such as profession, market, education, marriage, etc. It became communicative practice which mentioned by Subyakto \& Nababan in Hermawan (2014) that a group conversation with simple story titles and Supportive environment made the students forced to speak Arabic every day. From the environment, they learnt Arabic dialect, intonation and how to express it.

In other trainings, the students learnt the art of speaking or the way to speak Arabic properly. The students learnt the words or sentences by uttering their lecturer's example and imitating it. Another resource used was a part of Arabic movie on YouTube. The movie dialogues used as example in Arabic language were the episode of Yusuf Ash-Shidiq, Umar Mukhtar and Al-Risalah. From parts of the movies, there were several terms used in

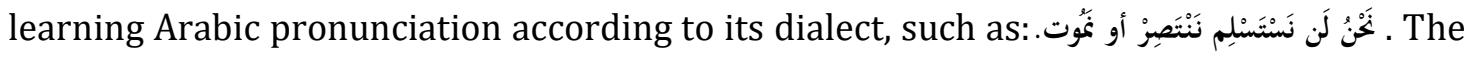
students imitated the terms in line with the intonation uttered, dialect, expression and pronunciation in the movie.

Dawood (2009) mentions that scientific training of Isma' wa Takallam method is listening stage for simulation, comprehension, and aesthetic taste. The first training phase is the learning process for simulation which the students only analyze, observe, listen, and imitate to what their lecturer's exemplified. The second is listening for comprehension. It is done by practical training, either in group or individually, and training for daily language in various situations. The training was carried in group conversation subject based on predetermined theme in daily life and speaking practice individually by telling experience/activities and explaining verse of poetry that had been learned in the classroom. This phase is based on guidebook/dictation guideline used. The third is listening for aesthetic taste. Al-Qur'an gives us detailed questions on listening and environment when we can distinguish. During learning process, the students started to comprehend the use of different words with similar meaning in certain sentence to distinguish them.

The learning process of Isma' wa Takallam method is implemented in two main stages, they are listening and speaking (Dawood, 2009). The first stage is listening, including: what we listen, what is listened often repeated, and how to listen. There are four elements in what to listen, they are: 
The First element is Al-Qur'an. It gives us the best model for the best listening when we listen to reciter who reads by implementing tajweed rules; therefore, we listen to the reciting and good pronunciation. In the learning process, the first stage is learning the Arabic alphabet sounds correctly, then practiced by reciting Al-Qur'an as well as tajweed every day. It trains the students in pronouncing Arabic sounds correctly and also trains listening skill by often listening to reciting Al-Qur'an.

The second element is formal language/fusha. It is obtained from news bulletin, listening to speech in fusha language, movie, etc. During learning process, the lecturers who taught and the teachers (ustadz/ustadzah) who supervised the students always used official language/fusha. Thus, the students always listened and spoke Arabic language. Dawood (2009) explains that art plays important role to improve speaking skill through several movies, such as Umar Mukhtar, and some serial movies for instance: Omar Bin Abdul Aziz, Sofyan Ats-Tsauri, Yusuf As-Siddiq, Salahuddin, etc. However, in the learning process, the students only utilized film of Umar Mukhtar, Yusuf As-Siddiq, and Al-Risalah. The students observed, listened, and imitated dialogues using various expression from the movies.

The third element is listening which often be repeated. Repeating the listening form, a source is essential to make sure that it is recorded consciously with clear description. It can strengthen our simulation. In the process, the students always listened to reciting of Al-Qur'an which was always repeated, and conversations or materials which were always listened while studying.

The fourth element is finding out the correct listening steps. Those steps are; firstly, listening, recognizing, and simulating sound. These steps exist as long as learning process preceded by listening to Arabic alphabets, words, sentences and imitating them correctly. Secondly, it is listening for comprehension. This step is not only to learn the pronunciation (understanding words and sentences). The next point of listening issue is learning correct pronunciation. When a lecturer explained a lesson; the students must understand words and sentences uttered. Due to frequently listening to similar words and sentences, the students more understand what conveyed. After that, the students learned to pronounce Arabic language correctly. Thirdly, listening is aesthetic taste of what is listened, either words or sentences. Al-Qur'an gives us detailed questions on listening and environment when we can distinguish (أصغى استمع ,سمع , أنصت, and). During learning process that was getting longer, the students started to comprehend the use of different words with similar meaning in certain sentence and was able to distinguish them.

The second stage of learning process of Isma' wa Takallam method is the art of speaking. There are eight elements in speaking art; they are: clarity, speed of utterance, raising intonation, clarity and coherent utterances, speech order, avoid compulsion/discomfort in speaking, pause and continue good/proper utterance, and maintain Arabic structure/grammar. In this stage, the students learnt the art of speaking from a part of movie entitled Umar Mukhtar. From the movie, the students listened, observed, and analyzed how the characters speak, the way they talk with appropriate expression with the condition, suitable intonation, typical Arabic dialect, etc. After 
analyzing, the students imitated a part of dialogues with similar pronunciation as the characters did.

Both of the learning stages have a slight difference with a study held by Lutfiana (2010) in teaching kalam. In her study, a teacher gave a lesson by practicing conversation (hiwar) and the students listened to the materials uttered. Then, the teacher asked the students to imitate what was uttered by the teacher properly. At the end of the lesson, the students are asked to demonstrate what had been learned in pairs. The difference of Lutfiana's stages with the stages described in this research was the lecturer gave lesson in the form of conversation (hiwar), Arabic alphabet sound system, then words and sentences, in the similar way: listening and then imitating. Moreover, the practice of conversation (muhadatsah) in pairs using predetermined theme with no preceding example from lecturer.

Isma' wa Takallam learning method uses drilling technique intensively. Ba'labaki (1990) stated that the drilling technique becomes the main method in the learning process. Drilling is a technique in language teaching used by all teachers in forcing students to repeat and to utter a sentence pattern correctly without any error (Hermawan, 2014: 185186).

The learning atmosphere, according to Ridhla as the representative of the third-year students of Arabic Department, was sometimes not conducive due to very cold weather and lack of rest which lead them feel sleepy in the morning class. The conduciveness also depends on mood/lecturer who teaches; however, the material presented is good since it is appropriate with them. A lot of learning activities from morning to evening, and also assignment made the students lack of rest. According to Ulfa, as the representative of the four year-students of Arabic Department, the learning atmosphere was pleasant if the lecturer could utilize media and teaching method properly, like media of image, singing, playing, and telling about life in Egypt as the teaching strategy to improve the students' learning interest.

Learning materials used in Isma' wa Takallam method were printed books, brochures (muhtawiyat), dictation guidelines, images, movies and environment that support listening and speaking skills. Majid (2013: 174) said that learning material can be classified into four categories: printed material, audio material, audio-visual material, and interactive teaching material. Learning materials used in this method such as printed book, brochure (muhtawiyat), dictation guideline, and image are classified into printed material category; while movie is classified into audio-visual learning material.

Teaching material in the form of text book classified formal and environment classified informal as pointed out by Iskandarwassid \& Sunendar (2011: 24) that formal material is the lesson that contained in official textbook at school; while, informal material refers to learning materials derived from school environment concerned. Formal textbook used is Nurul Bayan learning book entitled Nurul Bayan li Ta'limil Qir'ahwa Tartilil Quran, tajweed pocketbook, and a book entitled Maladzul Amin for reading Arabic text lesson. Then, from the surrounding environment, the students always listened to Arabic conversation or interact with Arabic people that support their listening and speaking skills. 
Teaching materials on Nurul Bayan are in accordance with Isma' wa Takallam method, that is eliminating assimilation of Arabic pronunciation which shares similar sounds with mother tongue and coping with Arabic sounds which are difficult to pronounce since the pronunciation sound system used to utter sounds of mother tongue, such as : (ص, ض, ظ, عong Indonesian students (Dawood, 2009). Furthermore, the Arabic speaking materials are listening to a lot of conversations of around Egyptians or interact with them, and imitating parts of movie dialogue on YouTube. This material is in line with the objective of Isma' wa Takallam method, that is obtaining listening (Istima') skill in various level, and Arabic speaking fluently and easily without arbitrariness and training on easiness in Arabic pronunciation with melody based on appropriate meaning such as happiness, sadness, question, amazement, disagreement, etc. (Dawood, 2009).

The materials are very useful in listening and speaking skills. Speaking skill (maharah kalam) is ability to express sounds of articulation or words to express thought in the form of idea, opinion, desire, or feeling to interlocutor. Speaking skill aims that students can communicate orally and properly using language that has been learned. Thus, it needs activities that support communication performance. Subyakto \& Nababan in Hermawan (2014: 135) divide the activity into two categories, they are precommunicative and communicative. Researchers classified materials of Nurul Bayan and Arabic language into pre-communicative training; while, speaking practice inside and outside classroom as communicative training (Hermawan, 2014).

Table 2. Material Classification based on Kinds of Speaking Practice

\begin{tabular}{|c|c|c|}
\hline NO. & Kinds of Practice & Material Presented \\
\hline \multirow[t]{6}{*}{1.} & Pre-communicative: & \\
\hline & $\begin{array}{l}\text { 1.1 Dialogue memorization: } \\
\text { Imitate and memorize }\end{array}$ & $\begin{array}{l}\text { - Memorizing sentences in movie dialogue, } \\
\text { then imitating them according to the } \\
\text { characteristics on movie and the one that } \\
\text { exemplified by teacher repeatedly in } \\
\text { Arabic speaking practice. } \\
\text { - Imitating the lecturer's utterances on } \\
\text { Arabic sound system in Nurul Bayan } \\
\text { material. }\end{array}$ \\
\hline & $\begin{array}{l}\text { 1.2 Dialogue by using images: } \\
\text { Understand fact through } \\
\text { images }\end{array}$ & $\begin{array}{l}\text { - Discussing an image on students' } \\
\text { worksheet orally with the lecturer in } \\
\text { Arabic subject. }\end{array}$ \\
\hline & $\begin{array}{l}\text { 1.3 Guided dialog: Complete } \\
\text { the conversation }\end{array}$ & $\begin{array}{l}\text { - Conversation practice with the lecturer by } \\
\text { starting to ask question and the students } \\
\text { answer. }\end{array}$ \\
\hline & $\begin{array}{l}\text { 1.4 Dramatization of action: } \\
\text { Express activities }\end{array}$ & - Retelling the activities or experiences. \\
\hline & $\begin{array}{l}\text { 1.5 Pattern practice } \\
\text { technique: Sentence } \\
\text { improvement practice }\end{array}$ & $\begin{array}{l}\text { - Doing exercise on the students' worksheet } \\
\text { in Arabic subject. }\end{array}$ \\
\hline
\end{tabular}


2. Communicative:

2.1 Group conversation: Students take turn in expressing ideas which continued by the others in order to make a story

2.2 Role play: Lecturer give certain role

\subsection{Social expression practice: Social behaviors during communication}

\subsection{Direct Practice}

\subsection{Problem solving: Discussion}

- Students continue other friend's story with similar theme and the sentences must be different so it can form a complete story. It is conducted in group conversation activities.

- Lecturer gives certain role with theme on daily live and only notice the students during conversation.

- Lecturer or supervisor exemplifies social expression, such as admiration expression, happiness, farewell expression, and compliment in Egypt life. The students apply them in daily life when interact with native speaker.

- During field study, resting time and transaction, the students communicate with native speakers.

- Carry out discussion concerning education in Egypt and Indonesia, such as marriage or others in group discussion activities.

The materials had supported exercises to enhance Arabic speaking skill. However, learning activities were less due to only two months.

\section{Evaluation System of Isma' wa Takallam Method}

Evaluation of learning using Isma' wa Takallam method is conducted with the process of learning implementation. The lecturer conducts test of reciting and spelling AlQur'an correctly, either spoken or written, debriefing about the materials, Juz Amma memorization test, conversation test using predetermined theme, reading Arabic text, explaining verse of Arabic poetry that has been studied, and imitating dialogue of the movie. Then, final evaluation uses this method orally in every subject. This evaluation is based on Regulation of Minister of Education and Culture No. 22 year 2016, that is evaluating learning result during the learning process and in the end of subject by using this method and tools: oral test/action test and written test. Isma' wa Takallam method at Ma'had Mu'allimil Qur'an have no mid semester test and the lecturer only asks the questions in the end of lesson. In this method, there is only homework, daily exercise, and final test or oral test. This statement in line with Arfina (2016) that learning evaluation is only carried out by asking questions in the end of the lesson, giving homework, mid-term test, and final exam in the end of semester. It could be concluded that learning Arabic using Isma' wa Takallam method was attended by the students who were non-Arabic speaker. Based on preliminary observation in field, the students were less active in speaking Arabic; however, using this method, the students were more active, brave, and their Arabic speaking skill increased. 


\section{CONCLUSION}

Based on the result of the research conducted, the researcher concluded that the implementation of Arabic learning using Isma' wa Takallam method consisted of learning plan in which dictation book as learning guidelines, learning implementation which was suitable with general learning procedures, that was preliminary, core, and closing activities as well as learning evaluation by carrying out a test. Stages in this learning method were: (1) learning Arabic sound system using Nurul Bayan method, (2) learning Arabic language, (3) drilling/speaking practice.

The materials used in Isma' wa Takallam method were Nurul Bayan material, that was sound system based on place of articulation (makharijul huruf), spelling letters/words/sentences in Al-Qur'an, tajweed, and rhythm of reciting Al-Qur'an. Arabic language materials were basic rules, vocabularies, numbers, reading Arabic texts, and poems. Arabic speaking practice was done with conversation either in group or individual, telling story, imitating movie dialogue, and communicating with native speaker outside the classroom. Whereas, evaluation system used in Isma' wa Takallam method was oral test. The test was carried out during the lesson and at the end of learning process.

After conducting the study, the researcher recommended points, they were: (1) Isma' wa Takallam method could be used in Indonesia with native speaker as teacher and avoid teaching using mother tongue so the objective of learning Arabic as the medium of communications could be achieved. (2) The existence of syllabus and lesson plan before teaching could make learning process more directed and went in line with the objective that was going to be achieved. (3) Optimizing the existing facilities such as LCD projector, language laboratory, and media such as movie in Arabic language, recorded conversation, etc. (4) Organizing language environment every day by applying penalty in order to make the students accustomed, active and willing to communicate in Arabic.

\section{REFERENCES}

Achmad, S. (2017). Developing Language Students' Writing Skill by Applying InnovativeTeaching Strategy Model Based on Social and Local Wisdom Contexts. Journal of Arts \& Humanities, 6(12), 1-6. https://doi.org/10.18533/journal.v6i12.1309.

Afroni, M. (2019). Metode Sam'iyah Safawiyah dalam Penbelajaran Bahasa Arab, 2(1). https://ejournal.unwaha.ac.id/index.php/lahjah/article/view/382/304.

Al-Khuliy. (1986). Asaalibu Tadris Al-Lugah Al-'Arabiyah. Muţabi' Al-Farzadiq Litijaariyah.

Anshari, M. (2018). Akuisisi Bahasa Arab Pada Tatanan Gramatika dan Rasa Bahasa Bagi Pembelajar Non-Arab. Al-Fathin: Jurnal Bahasa Dan Sastra Arab, 1(1), 61-69. https://doi.org/10.32332/al-fathin.v1i01.1192.

Arfina, E. (2016). Penerapan Metode As-Sam'iyyah Asy-Syafawiyyah dalam Pembelajaran Maharah Al-Kalam Pada Kelas VII Madrasah Tsanawiyah Negeri Wonosari Tahun Ajaran 2015-2016. Thesis. UIN Sunan Kalijaga Yogyakarta.

Bloom, B. S. (1956). Taxonomy of Educational Objectives: Handbook 1, Cognitive Domain. David McKay. 
Chaer, A. (2009). Psikolinguistik: Kajian Teoretik. Yogyakarta: Rineka Cipta.

Dawood, M. (2009). Tariqah Isma' Wa Takallam (Nażriyah fi Binaail Qudrah Al-Lugawiyah Liktisaabi Maharah Al-Kalam).

Habib, S. (2013). Metode Pembelajaran Bahasa Arab. Pusat Kajian Ilmiah.

Harjanto. (2010). Perencanaan Pengajaran. Rineka Cipta.

Hermawan, A. (2014). Metodologi Pembelajaran Bahasa Arab. Remaja Rosdakarya.

Heryanto, F. (2016). Resume Kurikulum dan Pembelajaran.

Hidayat, S., \& Ashiddiqi, A. (2018). Metode I'rab Al-Qur'an dan Konvensional Sebagai Pembelajaran Bahasa Arab Bagi Non Arab di Ponpes Al-Madinah Boyolali. PROFETIKA, Jurnal Studi Islam, 19(2), 123-135. https://doi.org/10.23917/profetika.v19i2.8119.

Ibrahim, R., \& Syaodih, N. (2010). Perencanaan Pengajaran. Yogyakarta: Rineka Cipta.

Iskandarwassid, \& Sunendar. (2011). Strategi Pembelajaran Bahasa. Bandung: PT. Remaja Rosdakarya.

Lavi, S. (2015). Ta'lim Al-Lugah Al-'Arabiyah Al-Mu'aşirah. 'Aalimul Kitab.

Lutfiana, N. (2010). Aplikasi Metode Sam'iyah Syafawiyah dalam Pengajaran Kalam (Bahasa Arab) Siswa Kelas VIII di MTsN Ngemplak Sleman Yogyakarta. Thesis. Sunan Kalijaga Yogyakarta.

Majid, A. (2013). Strategi Pembelajaran. Bandung: PT. Remaja Rosdakarya.

Mawaddah, R. (2012). Pembelajaran Bahasa Arab Menggunakan Metode Sam'iyyah Syafawiyah Siswa Kelas VII dan VIII MTs Negeri Karangmojo Gunungkidul Yogyakarta Tahun Ajaran 2011/2012 (Sebuah Potret Pembelajaran Berbasis Psikologi Siswa). Thesis. UIN Sunan Kalijaga Yogyakarta.

Mufidah, N., \& Zainudin, I. (2018). Metode Pembelajaran Al-Ashwat. Al Mahāra Jurnal Pendidikan Bahasa Arab, 4(2), 199-218. https://doi.org/10.14421/almahara.2018.042-03.

Mustofa, A. D. (2018). Penilaian Keterampilan Mendengarkan di SMPN 2 Cawas Klaten (Studi Kasus Pelaksanaan Pembelajaran Bahasa Indonesia di Kelas VII Tahun 2017/2018). Thesis. Universitas Muhammadiyah Surakarta.

Nashri. (2014). Maharah Al-Istima': Dirasah fi Majaali Ta'lim Al-Lugah Al-'Arabiyah li Gairi Naţiqiin. Thesis. Universitas Dokuz September.

Nurfika, L. (2016). Penerapan Metode Sam'iyyah Syafawiyyah Untuk Meningkatkan Hasil Belajar Bahasa Arab Pada Peserta Didik Kelas IV MI Darussalam Kolomayan Wonodadi Blitar. Thesis. IAIN Tulungagung.

Ruswandi. (2011). The Teaching of Speaking in Big Class. Register Journal, 4(1), 65-88. https://doi.org/10.18326/rgt.v4i1.67-90.

Sa'id, T. (2009). Al-Fawaidah Al-Hasan Fii Syarhi Nurul Bayan.

Salam, Y. (2014). Peran Penutur Asli (Nathiq) Bahasa Arab dalam Meningkatkan Pemerolehan Keterampilan Berbicara Mahasiswa di STAIN Batusangkar.

Sauri, S. (2017). Kesantunan Berbahasa. Subang: Royyan Press.

Srimelisa, D., Thahar, H. E., \& Arief, E. (2019). Kontribusi Keterampilan Membaca Pemahaman Teks Deskripsi terhadap Keterampilan Menulis Teks Deskripsi Siswa Kelas VII SMP Negeri 1 Bayang Utara. Jurnal Pendidikan Bahasa Indonesia, 8(1), 53- 
61. https://doi.org/10.24036/103914-019883.

Sudrajat, A. (2008). Pengertian Pendekatan, Strategi, Metode, Teknik dan Model Pembelajaran. Bandung: PT Sinar Baru Algensindo.

Sukirman, D. (2012). Pembelajaran Micro Teaching. Kemenag.

Ulya, N. M. (2016). Pengaruh Metode Pembelajaran dan Tipe Kepribadian Terhadap Hasil Belajar Bahasa Arab (Studi Eksperimen PadaMAN1 Semarang). Nadwa: Jurnal Pendidikan Islam, 10(1), 1-25. https://doi.org/10.21580/nw.2016.10.1.867.

Viriya, C., \& Sapsirin, S. (2014). Gender Differences In Language Learning Style and Language Learning Strategies. Indonesian Journal of Applied Linguistics, 3(1), 7788. https://doi.org/10.17509/ijal.v3i2.270. 